\title{
Factors associated to the notification of congenital syphilis: an indicator of quality of prenatal care*
}

\author{
Fatores associados à notificação da sífilis congênita: um indicador de qualidade da \\ assistência pré-natal
}

\section{Factores asociados con la notificación de la sífilis congénita: un indicador de calidad de la atención prenatal}

Inacia Sátiro Xavier de França ${ }^{1}$, Joana D’arc Lyra Batista ${ }^{2}$, Alexsandro Silva Coura ${ }^{1}$, Cibely Freire de Oliveira ${ }^{1}$, Andressa Kaline Ferreira Araújo ${ }^{1}$, Francisco Stélio de Sousa ${ }^{1}$

Objective: to analyze factors associated to the notification of congenital syphilis. Methods: a cross-sectional documentary, quantitative study, made through the National System of Notifiable Diseases. The study consisted of 113 notified cases. A data collection form was used and Chi-square and Fisher tests were made. Results: women had prenatal exams (80.2\%), serologic testing before six months of pregnancy (46.7\%) and after (53.3\%). There was an association for the variables race $(p=0.005)$ and serological test $(p=0.044)$. The treatment of the pregnant woman was inadequate $(64.5 \%)$ and the partner was not treated (85.7\%). Conclusion: it was found that the number of cases is growing, increasing the possibility of children with severe sequelae. So improvements in prenatal care are still needed.

Descriptors: Syphilis, Congenital; Prenatal Care; Disease Notification.

Objetivo: analisar fatores associados à notificação da sífilis congênita. Métodos: estudo transversal, documental, quantitativo, realizado através do Sistema Nacional de Agravos de Notificação. Compuseram o estudo 113 casos notificados. Utilizou-se formulário para coleta de dados e efetuaram-se os testes Qui-quadrado e Fisher. Resultados: mulheres realizaram pré-natal $(80,2 \%)$, teste sorológico antes dos seis meses de gestação $(46,7 \%)$ e após $(53,3 \%)$. Houve associação para as variáveis raça $(\mathrm{p}=0,005)$ e realização do teste sorológico $(\mathrm{p}=0,044)$. Tratamento da gestante foi inadequado $(64,5 \%)$ e o parceiro não foi tratado $(85,7 \%)$. Conclusão: constatou-se que é crescente o número de casos, aumentando a possibilidade de crianças com sequelas graves. Por isso ainda é preciso melhorias na assistência pré-natal.

Descritores: Sífilis Congênita; Cuidado Pré-Natal; Notificação de Doenças.

Objetivo: analizar factores asociados a la notificación de la sífilis congénita. Métodos: estudio transversal, documental, cuantitativo, realizado a través del Sistema Nacional de Agravios de Notificación. Compusieron el estudio 113 casos reportados. Se utilizó el formulario para recopilación de datos y se efectuaron las pruebas de Chi-cuadrado y Fisher. Resultados: las mujeres recibieron atención prenatal $(80,2 \%)$, la prueba serológica antes de los seis meses de gestación $(46,7 \%)$ y después $(53,3 \%)$. Hubo asociación para variables raza $(\mathrm{p}=0,005)$ y realización de la prueba serológica $(\mathrm{p}=$ 0,044). El tratamiento de la mujer embarazada fue insuficiente $(64,5 \%)$ y la pareja no fue tratada $(85,7 \%)$. Conclusión: se encontró número creciente de casos, aumento de la posibilidad de niños con secuelas graves. Así, es preciso mejorías en la atención prenatal.

Descriptores: Sífilis Congénita; Atención Prenatal; Notificación de Enfermedad.

*Article from the paper entitled "Primary health care for the prevention of visual impairment in children", Universidade Estadual da Paraiba, Brazil, 2014.

${ }^{1}$ Universidade Estadual da Paraíba. Campina Grande, PB, Brazil.

${ }^{2}$ Universidade Federal de Campina Grande. Campina Grande, PB, Brazil.

Corresponding author: Inacia Sátiro Xavier de França

Rua Sérgio Rodrigues de Oliveira, 139. Alto Branco. CEP: 58401-566 - Campina Grande, PB, Brazil. E-mail: inacia.satiro@gmail.com 


\section{Introduction}

Congenital syphilis is a challenge for public health in Brazil, because although it is a disease of easy prevention, diagnosis and treatment, it is observed that there is an increase of incidence of this disease, especially associated to social inequalities and to the weakness in covering prenatal assistance offered to the population, mainly at the level of primary health care $^{(1)}$. On the other hand, such finding can reflect an improvement in the system of notification as well as the prevention of vertical transmission of the disease $^{(2)}$.

Increasing number of these notifications occurs not only in Brazil but worldwide, as syphilis annually affects about 12 million adults and 90\% of these new cases are in developing countries. In Brazil, it is estimated that the prevalence of syphilis in pregnant women ranges from $1.4 \%$ to $2.8 \%$ with a vertical transmission rate of $25 \%{ }^{(3)}$. The highest rates of notification of the congenital syphilis are in the Southwestern region, followed by the Northeastern region with $45.9 \%$ and $31.4 \%$, respectively ${ }^{(4)}$.

This disease has compulsory notification and is classified as a chronic, systemic, infectious and contagious disease of hematogenous dissemination of Treponema pallidum, through the placenta at any time during pregnancy or clinical stage of the disease during pregnancy untreated or inadequately treated. Among the most serious consequences left by the disease in the affected child are interstitial keratitis with blindness, neurological deafness, hydrocephaly and mental retardation ${ }^{(5)}$. Exposure to this disease during pregnancy has serious complications for the woman and for her child, being responsible for a high morbidity in intrauterine life, leading to miscarriage, stillbirth, neonatal mortality and early and late complications in newborns, in over $50 \%$ of the cases $^{(6)}$. The commitment arising from this infection during pregnancy also varies according to the factors such as time of fetal exposure to Treponema, maternal treponemal load, virulence, treatment of maternal infection and co-infection by human immunodeficiency virus or other diseases that cause immunodeficiency ${ }^{(5)}$.

It is known that to remove congenital syphilis from the list of diseases that cause problems in public health, particularly because it predisposes to the development of permanent disabilities in affected individuals, it is necessary to reduce its incidence to less than one case per one thousand newborns/year as it was determined by the Health Department. In this perspective, it is necessary to develop actions of prevention in prenatal and maternity wards, make active searches for pregnant women with syphilis and provide the complete and adequate treatment to the stage of the disease with penicillin, and ending such treatment in at least 30 days before the delivery, the partner being treated as well ${ }^{(7)}$.

Key factors which contribute to the failure in achieving the established targets for elimination or reduction of this disease are: obstacles to full access to health services, lack of request for carrying out the serological examination of pregnant women as recommended and the lack of approach to treatment and monitoring of the partners of those women with a positive result of the serological test ${ }^{(6)}$.

Because of the improvements found in public health in Brazil and strategies already established in primary care to combat this disease, it is interesting to know if the referred city is aware and obtains positive results or not concerning the prevention of that disease, bringing as contribution the improvement and/or dissemination of knowledge for the whole society aiming at the elimination of the cases and reduction of consequences of the disease. Thus, the following guiding question emerged: "How is the situation of cases of congenital syphilis in Campina Grande/PB"?

Within this reality and assuming that congenital syphilis is related to socio-demographic factors and the quality of prenatal care ${ }^{(2.6)}$, the study aimed at 
analyzing the factors associated to the notification of congenital syphilis.

\section{Method}

It is a study of documentary cross-sectional type with quantitative approach, made in the Epidemiological Surveillance sector of the County Health Department of Campina Grande/PB, Brazil, through the database available at the National System of Notifiable Diseases that has the information compiled in the forms of notification.

The study consisted of all the cases of congenital syphilis notified in the National System of Notifiable Diseases from 2007 to 2012, comprising a total of 113 cases. The cases in the year of 2006 were excluded, considering that it was the period of the beginning of the computerized sector and there were no registers yet as well as the cases of 2013 for not having a consolidated quantitative figure.

Data collection made in two periods of March 2013, one day for the authorization of the search of data by part of the board of the sector, and another day for the data collection. A form based on the content of the chips of the National System of Notifiable Diseases available online was used.

The variables analyzed consisted of the number of cases of congenital syphilis notified yearly (2007-2012), maternal age and of child attacked by the disease, the research area, race and maternal education, Venereal Disease Research Laboratory serological test, prenatal exam and treatment of pregnant women whose newborns were diagnosed with congenital syphilis and the treatment of their partners.

Once the data were collected, the statistic analysis was made using the Statistical Package for Social Sciences version 20.0 software, measuring the data through absolute and relative frequencies. To compare the proportions of the identified frequencies, the chi-square test was used, considering an interval of confidence of $95 \%$, and the data were presented in tables. In the case of frequencies below five units, the Fisher's Test was used.

The incidence rate for each year studied was calculated by dividing the number of cases of congenital syphilis of a given year by the number of newborns of the same year, and the incidence expressed per 1,000 newborns. For this procedure, data supplied by the system of information on newborns were used, available by the system on-line of the Health Departament. It is worth mentioning that the incidence rate was calculated until the year of 2011 due to the lack of data concerning the number of newborns in year 2012.

\section{Results}

Data indicate increasing tendency in the incidence of syphilis, as shown in Figure 1.

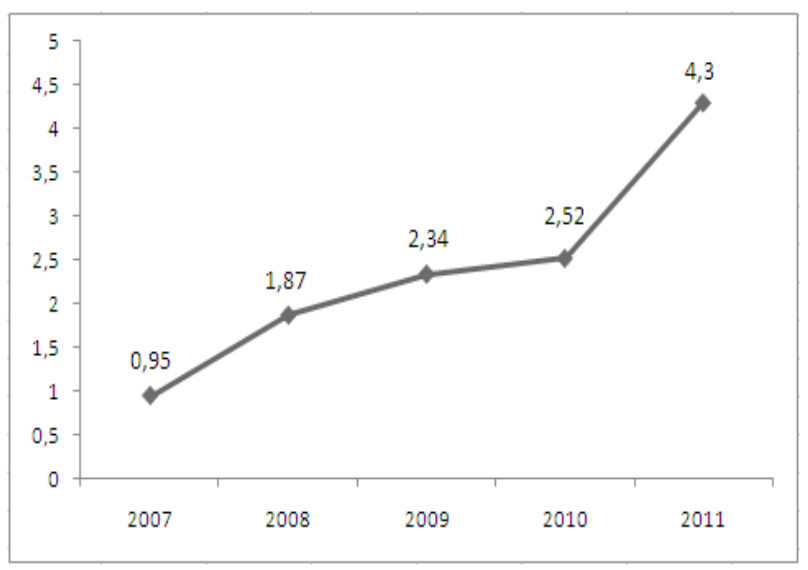

Figure 1 - Notification of cases of congenital syphilis

In Table 1, it is found that the only factor with significant association related to the notification of congenital syphilis over the years was the maternal race $(\mathrm{p}=0.005)$.

Table 2 presents the procedures related to prenatal care and treatment of congenital syphilis. The only factor with significant association related to the notification of congenital syphilis over the years has been the serological test $(p=0.044)$. 
Table 1 - Maternal and child Profile related to the notification of congenital syphilis

\begin{tabular}{|c|c|c|c|c|c|c|c|c|}
\hline \multirow{2}{*}{ Maternal and child profile } & 2007 & 2008 & 2009 & 2010 & 2011 & 2012 & Total & $\mathbf{p}$ \\
\hline & n (\%) & n (\%) & n (\%) & n (\%) & n (\%) & n (\%) & n (\%) & \\
\hline \multicolumn{9}{|l|}{ Maternal age range } \\
\hline $15-34$ & $5(83.3)$ & $10(83.3)$ & $13(86.7)$ & $11(68.7)$ & $23(85.2)$ & $34(91.9)$ & $96(84.9)$ & 0.446 \\
\hline $35-54$ & $1(16.7)$ & $2(16.7)$ & $2(13.3)$ & 5 (31.3) & $4(14.8)$ & $3(8.1)$ & $17(15.1)$ & \\
\hline \multicolumn{9}{|l|}{ Maternal race* } \\
\hline White & $3(50.0)$ & $5(41.7)$ & $4(26.7)$ & $1(6.3)$ & $2(7.7)$ & $3(8.1)$ & $18(16.1)$ & 0.005 \\
\hline Non-white & $3(50.0)$ & 7 (58.3) & 11(73.3) & $15(93.7)$ & $24(92.3)$ & $34(91.9)$ & $94(83.9)$ & \\
\hline \multicolumn{9}{|l|}{ Maternal education ${ }^{\dagger}$ (years) } \\
\hline$\leq 10$ & $6(100.0)$ & $10(100.0)$ & $12(85.7)$ & $14(100.0)$ & $17(73.9)$ & $22(70.9)$ & $81(82.6)$ & 0.060 \\
\hline$>10$ & - & - & $2(14.3)$ & - & $6(26.1)$ & 9 (29.1) & $17(17.4)$ & \\
\hline \multicolumn{9}{|l|}{ Child's age (years) } \\
\hline$<1$ & $6(100.0)$ & $12(100.0)$ & $15(100.0)$ & $16(100.0)$ & $26(96.3)$ & $36(97.3)$ & $111(98.2)$ & 0.895 \\
\hline $1-4$ & - & - & - & - & $1(3.7)$ & $1(2.7)$ & $2(1.7)$ & \\
\hline \multicolumn{9}{|l|}{ Home area } \\
\hline Urban & $6(100.0)$ & 11 (91.7) & 13 (86.7) & $16(100.0)$ & $27(100)$ & $37(100.0)$ & $110(97.3)$ & 0.063 \\
\hline Rural & - & $1(8.3)$ & $2(13.3)$ & - & - & - & $3(2.7)$ & \\
\hline
\end{tabular}

Table 2 - Procedures related to prenatal care and treatment related to notification of congenital syphilis

\begin{tabular}{|c|c|c|c|c|c|c|c|c|}
\hline \multirow{2}{*}{ Procedures } & 2007 & 2008 & 2009 & 2010 & 2011 & 2012 & Total & $\mathbf{p}$ \\
\hline & n (\%) & n (\%) & n (\%) & n (\%) & n (\%) & n (\%) & n (\%) & \\
\hline \multicolumn{9}{|l|}{ Prenatal exam ${ }^{\ddagger}$} \\
\hline Yes & $5(83.3)$ & $9(75.0)$ & $15(100.0)$ & $14(93.3)$ & $18(66.7)$ & $28(77.7)$ & $89(80.2)$ & 0.116 \\
\hline No & $1(16.7)$ & $3(25.0)$ & - & $1(6.7)$ & $9(33.3)$ & $8(22.3)$ & $22(19.8)$ & \\
\hline \multicolumn{9}{|l|}{ Serological test ${ }^{\S}$ (months) } \\
\hline$\leq 6$ & - & $4(36.4)$ & $5(33.3)$ & $10(62.5)$ & $10(38.5)$ & $21(61.7)$ & $50(46.7)$ & 0.044 \\
\hline$>6$ & $5(100)$ & $7(63.6)$ & $10(66.7)$ & $6(37.5)$ & $16(61.5)$ & $13(38.3)$ & $57(53.3)$ & \\
\hline \multicolumn{9}{|l|}{ Notification" } \\
\hline Prenatal & $4(66.7)$ & 7 (58.3) & $6(40.0)$ & $5(33.3)$ & $13(48.2)$ & $21(60.0)$ & $56(50.9)$ & 0.457 \\
\hline Delivery or postpartum & $2(33.3)$ & $5(41.7)$ & $9(60.0)$ & $10(66.7)$ & $14(51.8)$ & $14(40.0)$ & $54(49.1)$ & \\
\hline \multicolumn{9}{|l|}{ Treatment/pregnant** } \\
\hline Adequate & $1(16.7)$ & $1(8.3)$ & $2(13.3)$ & $3(21.4)$ & $3(11.1)$ & $2(5.6)$ & $12(10.9)$ & 0.694 \\
\hline Inadequate & $5(83.3)$ & $11(91.7)$ & 13(86.7) & $11(78.6)$ & $24(88.9)$ & $34(94.4)$ & 98 (89.1) & \\
\hline \multicolumn{9}{|l|}{ Treatment/partner ${ }^{\dagger \dagger}$} \\
\hline Yes & $1(16.7)$ & $1(8.3)$ & $3(20.0)$ & $5(41.7)$ & $3(12.5)$ & $2(5.5)$ & $15(14.3)$ & 0.064 \\
\hline No & $5(83.3)$ & $11(91.7)$ & $12(80.0)$ & 7 (58.3) & $21(87.5)$ & $34(94.5)$ & 90 (85.7) & \\
\hline
\end{tabular}




\section{Discussion}

The city of Campina Grande is the second most populous in the state of Paraíba, located in the countryside of that state, with an estimated population of 385,276 inhabitants, according to the last census in 2010. Furthermore, it has the second highest Gross Domestic Product among the surrounding counties, and the metropolitan area consists of $15 \operatorname{counties}^{(8)}$. In this study, the county of Campina Grande presented a growth in the incidence of congenital syphilis from 2007 to 2012, a datum that was also found in other Brazilian cities such as Belo Horizonte,MG, Sobral,CE, and the state of Ceará ${ }^{4,6,9}$ ).

The above situation reflects two opposing possibilities. The first is related to a possible improvement in the quality of notifications in the National System of Notifiable Diseases, possibly due to the increased frequency of diagnosis in pregnant women and newborns, modification occurred in the definition of the case of congenital syphilis in 2004 and the introduction of compulsory serological test at birth as a condition to receive financial incentives through the Unified Health System. A research made with the data of the National System of Notifiable Diseases, in Belo Horizonte,MG, from 2001-2008, on the incidence and risk factors for congenital syphilis, also referred to the above mentioned conclusions ${ }^{(2)}$.

The second justification may be related to deficiencies that remain in primary care in the country, especially at the time of prenatal care. Although the results indicate a considerable increase in the adhesion to the prenatal appointments and therefore an earlier diagnosis of infection, the treatment of pregnant women and their partners is still largely inadequate most of their partners are not treated, thus contributing to undesirable outcomes.

Among the notified cases, because it is a period of five years in a county with a population of women who according to the Brazilian Institute of Geography and Statistics is around 203,027, it is believed that the figure identified in the study is lower than expected. This fact is possibly due to underreporting, once it confirms another study based on the National System of Notifiable Diseases, which states that underreporting in the country in average reaches $67 \%$ a year. The study attributes the existence of cases to the needs of expanding access to health services, effective action to control the disease, health education and strengthening of prenatal once this disease is entirely preventable ${ }^{(9)}$.

Because the highest number of notifications are in the urban area it is believed to be linked to better coverage of primary care in the county once there is still a greater quantity of units in urban areas at the expense of rural, showing existing inequalities. A similar result was found in a study regarding the procedures of prenatal care recommended by the Humanization Program of Prenatal and Birth nationwide which identified a low proportion of complementary tests as the test for syphilis in pregnant women living in rural areas compared to those living in urban areas ${ }^{(10)}$.

Regarding most of the notifications in children under one year, the data highlighted by the study are in accordance with the strategies of the Health Department for children's health. It is possible that early notification occurs before the first year of life, for being related to a higher frequency in maternal and child health services, considering that it is in this period that neonatal screening occurs, monitoring of growth and development, immunizations, health education to encourage breastfeeding among other activities that are important for the promotion, prevention and treatment of children's diseases ${ }^{(11)}$.

Also concerning the above mentioned datum, it is feasible to mention the attendance to children's appointments as a result of a condition of the government programs of transferring funds such as Bolsa Familia that requires monitoring of the beneficiaries in three sectors: education, welfare and health, and the latter requires the monitoring of 
growth child development, vaccination of children under seven years, and prenatal and postpartum care $^{(12-13)}$.

Regarding the socio-demographic profile of pregnant women infected with syphilis, this result confirms another research that compared two periods in a population of mothers for verification of congenital syphilis and prenatal care factor in Campo Grande-MS, which reports that most of pregnant women affected by this infection are teenagers and young adults, as well as the ones living in the urban area ${ }^{(14-15)}$. This age range of infected women portrays the practice of early and careless sexual activity, reinforcing the idea that it is still necessary to improve health education strategies to raise awareness for safe sexual practice ${ }^{(9)}$.

Because most children infected come from dark-skinned mothers this rate can be related to the lack of knowledge by part of the women on the definition of which race and also because this is a self-reported feature. It was possible to see that race was the only factor of socio-demographic profile that was significantly associated to the notification of congenital syphilis, the result is similar to the one which identified as independent risk factors for congenital syphilis the dark or black skin of the mother, low maternal education and lack of prenatal appointments $^{(2)}$.

As to education, a research made in Anapolis,GO, with 59 pregnant women identified different profile of cases of syphilis by identifying good level of education in women participating in the study ${ }^{(15)}$. By contrast, in Olinda,PE, with 234 cases of congenital syphilis, most of the women who had their children infected had not finished grade school, being in accordance with the percentages found in this study, strengthening the relation of the low level of education to different diseases ${ }^{(16)}$.

Regarding the adhesion to prenatal care, it possible to see that even with many impasses it grew nationwide, a conclusion made with data of the research Nascer no Brasil, held in 2011 and 2012, indicating high coverage of prenatal care especially in public service offered to pregnant women ${ }^{(17)}$. It is highlighted that the quality of prenatal care which showed the understanding of nurses about the integration of actions in prenatal care, besides providing reduction of maternal morbidity and mortality, it is still a determining factor in the elimination of congenital syphilis ${ }^{(18)}$.

As a result of the increase in the adhesion to prenatal care, this was the moment of greatest notifications of cases, followed by the notification in postpartum. However, the findings point to a problem regarding the time of the serological test, once a considerable percentage of the cases had the exam in the follow-up concerning the ignored gestational age. This finding raises a concern about the prognosis of the disease, since the sooner it is diagnosed and treated, the better it will be, minimizing the time of exposure of the fetus to treponema ${ }^{(5)}$. It is reported that in the metropolitan area of Fortaleza, in the first appointment, $25 \%$ of pregnant women did not receive request for serological test, a fact that amplifies the problem $^{(19)}$.

The serological test also had significant association to the notified cases, thus showing the importance of the same at the recommended time, which is the first and the last quarter of pregnancy. Similar results were not found in the literature and the significant associations concerning sociodemographic characteristics and related or not to prenatal appointments were more expressive.

Concerning the treatment of pregnant women, this study aims at the need of improvement, once many of the notified cases had inadequate treatment being characterized as any treatment that is not made with penicillin or is incomplete or inconsistent with the clinical stage of the disease and if it is made within 30 days before delivery, there is no supporting documentation and does not present reduction in the titles of serology, or have their partners untreated, inadequately treated or with the treatment ignored ${ }^{(7)}$. 
This deficit found in the adequate treatment for pregnant women has also been identified in the literature and mainly associated to poverty that prevents full access to the health service, due to the level of education and lack of knowledge about sexually transmitted diseases and their potential complications, bringing with it the fear that discourages users to stay in treatment or even accept it ${ }^{(16)}$.

The same was found regarding the treatment of the partner in which most have not been treated, which contributes negatively to the persistence and spread of the disease and is mainly explained by the low adhesion to the health service by the male population, either by employing reasons or lack of knowledge about the importance of caring for the health and the consequences that the disease can bring to the fetus and to the couple ${ }^{(6.16)}$.

\section{Conclusion}

Despite the fact that the limitations of the study are related to the reduced number of cases and the impossibility to consider the data from 2006 to 2013, it was possible to reach the proposed objective, once the factors associated to the notification of congenital syphilis were analyzed in Campina Grande, PB, showing association concerning the variable maternal race and serological test.

It was found that the number of cases of congenital syphilis in the county is growing, increasing the possibility of children with severe physical, behavioral and social sequelae, diseases that jeopardize the quality of life. Even being an already known disease, with diagnosis and treatment well established and focused on consolidated prenatal care, improvement in primary care is still necessary, both in the strengthening of health education or even in the rigor with which it the disease is detected and treated.

It is suggested that the findings contribute to alert health professionals and government agencies about the need to implement improvements in the health service, increase the divulgation of the disease and its outcomes, favoring primary prevention of congenital syphilis and its more serious consequences such as the permanent disabilities.

\section{Acknowledgements}

To the collaborators of the study, to the technical reviewers, to the city hall of Campina Grande,PB for supplying the epidemiological data and the financing of the research through the Master's degree scholarship provided by the Coordination of Improvement of Higher Education Personnel.

\section{Collaborations}

França ISX e Batista JDL contributed in the conception, outlining, analysis and interpretation of the data, the writing and the critical revision of the article. Coura AS, Oliveira CF, Araújo AKF e Sousa FS contributed in the analysis and interpretation of the data, the writing, the critical revision and the final approval of the version to be published.

\section{References}

1. Araujo CL, Shimizu HE, Sousa AIA, Hamann EM. Incidência da sífilis congênita no Brasil e sua relação com a Estratégia Saúde da Família. Rev Saúde Pública. 2012; 46(3):479-86.

2. Lima MG, Santos RFR, Barbosa GJA, Ribeiro GS. Incidência e fatores de risco para sífilis congênita em Belo Horizonte, Minas Gerais. 2001-2008. Ciênc Saúde Coletiva. 2013; 18(2):499-506.

3. Campos AL, Araújo MAL, Melo SP, Gonçalves MLC. Epidemiologia da sífilis gestacional em Fortaleza, Ceará, Brasil: um agravo sem controle. Cad Saúde Pública. 2010; 26(9):1747-55.

4. Ministério da Saúde (BR). Secretaria de Vigilância em Saúde. Departamento de DST, AIDS e Hepatites Virais. Boletim Epidemiológico-sífilis. Brasília: Ministério da Saúde; 2012. 
5. Ministério da Saúde (BR). Secretaria de Vigilância em Saúde. Departamento de Vigilância Epidemiológica. Doenças infecciosas e parasitárias: guia de bolso. Brasília: Ministério da Saúde; 2010.

6. Mesquita KO, Lima GK, Filgueira AA, Flôr SMC, Freitas CASL, Linhares MSC, et al. Análise dos casos de sífilis congênita em Sobral, Ceará: contribuições para assistência pré-natal. J Bras Doenças Sex Transm. 2012; 24(1):20-7.

7. Ministério da Saúde (BR). Secretaria de Vigilância em Saúde. Programa Nacional de DST/AIDS. Diretrizes para controle da sífilis congênita: manual de bolso. Brasília: Ministério da Saúde; 2006.

8. Instituto Brasileiro de Geografia e Estatística (BR). Contagem Populacional. [Internet] 2010 [citado 10 jan 2014]. Disponível em: http:www.ibge.gov. br/home/estatistica/populacao/censo2010/ tabelas_pdf/total_populacao_paraiba.pdf

9. Costa CC, Freitas LV, Sousa DMN, Oliveira LL, Chagas ACMA, Lopes MVO, et al. Congenital syphilis in Ceará: epidemiological analysis of one decade. Rev Esc Enferm USP. 2013; 47(1):152-9.

10. Cardoso LSM, Mendes LL, Meléndez GV. Antenatal care differences in brazilian urban and rural areas: a cross-sectional population-based study. Rev Min Enferm. 2013; 17(1):85-92.

11. Silva AG, Moraes CL, Reichenheim ME. Violência física entre parceiros íntimos: um obstáculo ao início do acompanhamento da criança em unidades básicas de saúde do Rio de Janeiro, Brasil. Cad Saúde Pública. 2012; 28(7):1359-70.
12. Carvalho AT, Almeida ER, Nilson EAF, Ubarana JÁ, Fernández IM, Immink M. Métodos de análise em programas de segurança alimentar e nutricional: uma experiência no Brasil. Ciênc Saúde Coletiva. 2013; 18(2):309-21.

13. Ramos CI, Cuervo MRM. Programa Bolsa Família: a interface entre a atuação profissional e o direito humano a alimentação adequada. Ciênc Saúde Coletiva. 2012; 17(8):2159-68.

14. Figueró-Filho EA, Freire SSA, Souza BA, Aguena GS, Maedo CM. Sífilis e gestação: estudo comparativo de dois períodos (2006 e 2011) em população de puérperas. J Bras Doenças Sex Transm. 2012; 24(1):32-7.

15. Almeida KC, Lindolfo LC, Alcântara KC. Sífilis em gestantes atendidas em uma unidade de saúde pública de Anápolis, Goiás, Brasil. Rev Bras Anal Clin. 2009; 41(3):181-4.

16. Brito ESV, Jesus SB, Silva MRF. Sífilis congênita como indicador de avaliação da assistência ao prénatal no município de Olinda (PE), Brasil. Rev APS. 2009; 12(1):62-71.

17. Viellas EF, Domingues RMSM, Dias MAB, Gama SGN, Filha MMT, Costa JV, et al. Assistência prénatal no Brasil. Cad Saúde Pública. 2014; 30 (supl. 1):85-100.

18. Saraceni V, Miranda AE. Relação entre cobertura da estratégia saúde da família e o diagnóstico de sífilis na gestação e sífilis congênita. Cad Saúde Pública. 2012; 28(3):490-6.

19. Valente MMQP, Freitas NQ Áfio ACE, Sousa CSP, Evangelista DR, Moura ERF. Prenatal care: a look at the quality. Rev Rene. 2013; 14(2):280-9. 